\title{
RESULTS OF COMPOSITION ANALYSIS OF NON-GRAIN PART OF MAJOR FIELD CROPS IN UKRAINE
}

\author{
Viacheslav Bratishko $^{1}$, Tetiana Tkachenko ${ }^{2}$, Serhii Shulha ${ }^{3}$, Olena Tigunova ${ }^{3}$ \\ ${ }^{1}$ National University of Life and Environmental Sciences of Ukraine, Ukraine; \\ ${ }^{2}$ V.P. Kukhar Institute of Bioorganic Chemistry and Petrochemistry of NAS of Ukraine, Ukraine; \\ ${ }^{3}$ Institute of Food Biotechnology and Genomics of NAS of Ukraine, Ukraine \\ vbratishko@gmail.com,ttv13ttv@gmail.com,shulga5@i.ua, tigunova@ukr.net
}

\begin{abstract}
In recent decades, the share of plant raw materials in the production of solid, liquid, and gaseous fuels has increased significantly. One of the promising sources of bio raw materials, the efficiency of which can be increased, is the non-grain part of the crops of agricultural plants. Today, the main crops in Ukraine, as in most Eastern European countries, are corn, wheat, sunflower, barley, soybeans and rapeseed. The total share of production of all other crops of the agricultural sector of Ukraine does not exceed $2 \%$. The efficiency of further use of the non-grain part of the crop of these cultures significantly depends on the content of the main macro components - cellulose, hemicellulose, and lignin, which varies depending on the plant species. Using standardized methods of laboratory tests, a chemical analysis of the parameters and composition of the non-grain part of these most common crops was performed in this study. According to the obtained results the highest content of watersoluble substances was observed in the non-grain part of corn (19.8\%) and sunflower (16.1\%); cellulose in barley $(50.0 \%)$, soybeans $(46.9 \%)$ and wheat $(46.5 \%)$; hemicellulose in sunflower $(43.5 \%)$, soybeans $(36.3 \%)$ and rapeseed (35.5\%); lignin in barley $(24.2 \%)$ and rapeseed $(16.7 \%)$. The results of lignocellulosic biomass composition analysis in terms of lignin content and ash content do not coincide with the common conclusions that samples with a lower lignin content also have a lower ash content. Thus, the highest ash rates are in sunflower $(14.7 \%)$, corn (9.0\%) and rapeseed (8.0\%), while the lowest are in soybeans $(4.4 \%)$ and wheat $(6.5 \%)$. The highest total content of cellulose and hemicellulose makes the non-grain part of legumes soybeans (83.2\%) and rapeseed (79.2\%), which allowed us to make preliminary conclusions about the higher value of these crops for further use in biofuel technologies.
\end{abstract}

Keywords: lignin, cellulose, hemicellulose, field crops, biofuel.

\section{Introduction}

The climate crisis, one of the main causes of which is the human consumption of extractive resources, in particular hydrocarbons, and its consequences have led to a change in the energy policy of the world's leading countries towards a significant increase in the share of renewable energy and raw materials. In recent decades, the share of vegetable raw materials in the production of solid, liquid, and gaseous fuels has increased significantly. Ukraine, as one of the world leaders in the production of crop products, in particular cereals, annually receives tens of millions of tons of plant biomass, which is used for energy and other purposes. The results of previous studies show the possibility of significantly increasing the energy value of these raw materials using modern chemical, thermal, mechanical, and other processing methods, which is an urgent task [1-4].

The development of efficient technologies for the production of biofuels based on plant biomass [5-12] requires information on its composition, in particular, on the content of basic biopolymers (cellulose, hemicellulose, and lignin), pitches, fats, water-soluble substances, ash, and more. The aim of the research was to determine the parameters of the composition of the non-grain part of the crop of major field crops, which can be used as a raw material in technologies for production of solid, liquid or gaseous biofuels.

Today, Ukraine is one of the world's leading producers and exporters of crop products, which according to the Food and Agriculture Organization [13] and the World Bank is among the top ten producers [14] and the top five exporters. Taking into account the trends in the production of major crops, forecasts of the Organization for Economic Cooperation and Development and the Food and Agriculture Organization [15], the production of major legumes in Ukraine in 10 years will increase and will be: wheat -34 million tons; corn -39 million tons; barley -10.2 million tons.

In Ukraine, tens of millions of tons of plant bio-raw materials are produced annually - the non-grain part of the crop harvest. According to the Bioenergy Association of Ukraine [16], less than 1\% of the harvested straw is used for energy and solid biofuel production, i.e. there are significant reserves for further use of this bio-raw material. 
The main crops in Ukraine are corn, wheat, sunflower, barley, soybeans, and rapeseed. The ratio of grain and non-grain parts of these crops (waste ratio [17]) is in the range from 0.8 (barley) to 1.9 (sunflower). The total share of production of all other crops by agricultural enterprises of Ukraine last year did not exceed $2 \%$ (Fig. 1).

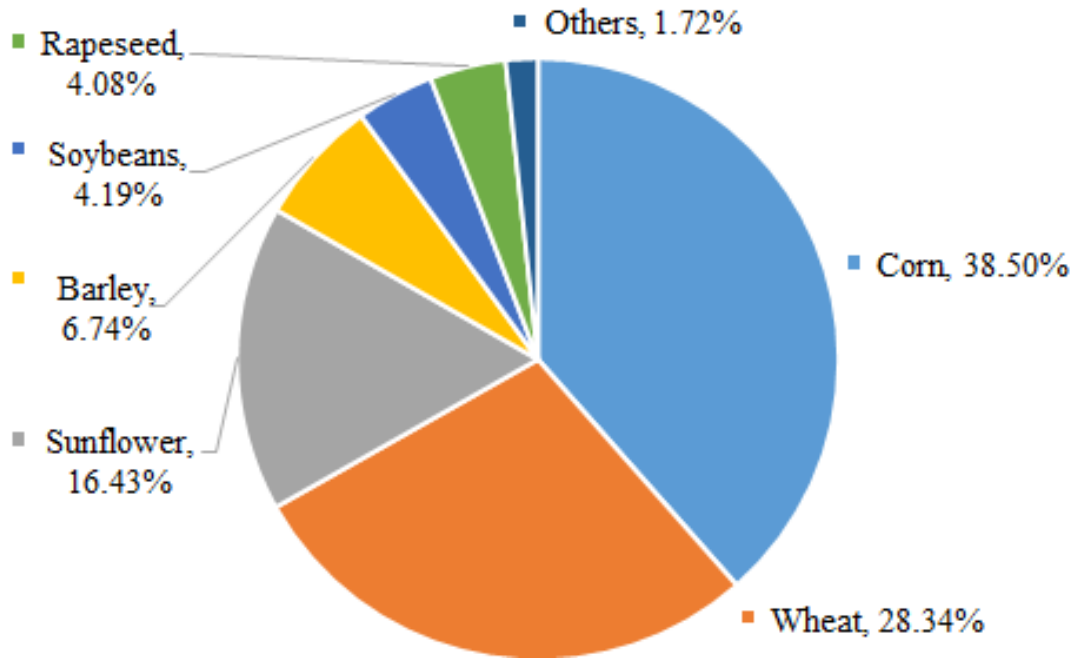

Fig. 1. Structure of production of major crops in agricultural enterprises of Ukraine in 2020

\section{Materials and methods}

Promising crops for use in biofuel production technologies in Ukraine have been identified by analysing the structure of the production of cereals and legumes of major crops in agricultural enterprises of Ukraine in 2020 (Fig.1). Therefore, as a raw material in this research we use non-grain part of the crop: straw of wheat, rye, rapeseed, barley, oat, soybean and stalk of sunflower, corn.

The humidity of each raw material was determined by the thermographic method at a temperature of $100-105^{\circ} \mathrm{C}$, according to the standard ISO 6496 [18], using the electronic scales-moisture meters series ADGS, which meet the requirements of the standard GOST 24104-88 [19].

The crude ash content was determined by the method of the standard GOST 26226-95 [20]. To do this, a sample weighing about 1-2 g (not more than half of the crucible) was placed in a pre-dried crucible. The crucible was weighed to the nearest $0.001 \mathrm{~g}$, then placed in a cold oven and the temperature was raised to $200-250^{\circ} \mathrm{C}$ until smoke appeared. After cessation of smoke, the furnace temperature was adjusted to $525 \pm 25^{\circ} \mathrm{C}$ and the crucible with the sample was calcined for 4-5 hours until the material was completely ash-dried.

The cellulose content was determined by the Kurschner nitrogen-alcohol method [21], using a nitrogen-alcohol mixture consisting of one volume of concentrated nitric acid $\left(1.4 \mathrm{~g} \cdot \mathrm{ml}^{-1}\right)$ and four volumes of $95 \%$ ethanol. Determination of lignin content was carried out by the method established by the standard GOST 26177-84 [22].

Determination of the content of substances soluble in hot water was carried out by placing a portion of dry samples weighing about $2 \mathrm{~g}$ from $100 \mathrm{ml}$ of distilled water in a conical flask with a capacity of $250 \mathrm{ml}$. A reflux condenser was connected to the flask and placed in a boiling water bath. Throughout the extraction ( 3 hours) was maintained a constant water level in the bath by adding boiling water. The sample was then filtered on a pre-dried to constant weight porous glass filter with suction, washing the sample from the flask to the filter with hot distilled water. The sample filter was dried to constant weight in an oven at $103 \pm 2{ }^{\circ} \mathrm{C}$ and weighed. The mass fraction of substances soluble in hot water (E) in percent was calculated by the formula:

$$
E=\frac{g-\left(m_{1}-m_{0}\right)}{g} \times 100,
$$

where $m_{0}-$ mass of empty filter, $\mathrm{g}$;

$m_{1}-$ mass of the filter with the sample residues, $\mathrm{g}$;

$g-$ mass of absolutely dry initial sample, $g$. 
Determination of the total content of hemicelluloses was carried out according to the method described in work [23]. Determination of pitch and fat content was carried out by the method of extraction according the standard GOST 6841-77 [24], using a Soxhlet-type installation.

Determination of the composition of the ash was carried out by the method of energy-dispersive Xray fluorescence analysis (XRF) on a precision analyser "EXPERT 3L" model U168, designed for direct operational non-destructive measurement of the mass fraction of chemical elements in the samples. The measurement result is a table of detected elements and their mass fractions.

\section{Results and discussion}

The results of raw material composition analysis are presented in Tables 1 and 2, and Fig. 2.

Composition of the non-grain part of the crops

Table 1

\begin{tabular}{|l|c|c|c|c|c|c|c|c|}
\hline $\begin{array}{c}\text { Raw } \\
\text { material }\end{array}$ & $\begin{array}{c}\text { Dry } \\
\text { matter, } \\
\mathbf{\%}\end{array}$ & $\begin{array}{c}\text { Ash, } \\
\mathbf{\%}\end{array}$ & $\begin{array}{c}\text { Pitches and } \\
\text { fats, \% }\end{array}$ & $\begin{array}{c}\text { Water-soluble } \\
\text { substances, \% }\end{array}$ & $\begin{array}{c}\text { Cellulose, } \\
\mathbf{\%}\end{array}$ & $\begin{array}{c}\text { Lignin, } \\
\mathbf{\%}\end{array}$ & $\begin{array}{c}\text { Hemi- } \\
\text { cellulose, } \\
\mathbf{\%}\end{array}$ & $\begin{array}{c}\text { Other, } \\
\mathbf{\%}\end{array}$ \\
\hline Wheat & 91.8 & 6.5 & 1.2 & 14.5 & 46.5 & 12.9 & 24.6 & 0.3 \\
\hline Rye & 90.6 & 6.2 & 1.8 & 7.7 & 46.1 & 15.5 & 28.8 & 0.1 \\
\hline Rapeseed & 89.9 & 8.0 & 0.9 & 3.0 & 43.7 & 16.7 & 35.5 & 0.2 \\
\hline Barley & 82.7 & 7.6 & 1.2 & 7.2 & 50.0 & 24.2 & 17.1 & 0.3 \\
\hline Oat & 80.4 & 7.1 & 2.1 & 16.1 & 40.2 & 10.0 & 31.2 & 0.4 \\
\hline Corn & 86.2 & 9.0 & 1.5 & 19.8 & 36.9 & 11.9 & 29.7 & 0.2 \\
\hline Soybean & 85.2 & 4.4 & 0.9 & 4.0 & 46.9 & 11.6 & 36.3 & 0.3 \\
\hline Sunflower & 78.2 & 14.7 & 2.5 & 16.1 & 27.5 & 10.3 & 43.5 & 0.1 \\
\hline
\end{tabular}

XRF analysis results of ash gained from the non-grain part of the crops

Table 2

\begin{tabular}{|l|c|c|c|c|c|c|c|c|c|c|c|c|}
\hline \multirow{2}{*}{$\begin{array}{c}\text { Raw } \\
\text { material }\end{array}$} & \multicolumn{10}{|c|}{ Content of main components (mass fractions) \% } \\
\cline { 2 - 14 } & $\mathbf{S i O}_{2}$ & $\mathbf{K}_{\mathbf{2}} \mathbf{O}$ & $\mathbf{C a O}$ & $\mathbf{T i O}_{2}$ & $\mathbf{F e}_{2} \mathbf{O}_{3}$ & $\mathbf{S O}_{2}$ & $\mathbf{S r O}$ & $\mathbf{M n O}_{2}$ & $\mathbf{P}_{2} \mathbf{O}_{\mathbf{5}}$ & $\mathbf{Z n O}$ & $\mathbf{C l}$ & $\mathbf{M g O}$ \\
\hline Wheat & 64.687 & 19.295 & 8.040 & - & 0.525 & 0.498 & - & 0.197 & 1.454 & - & 5.303 & - \\
\hline Rye & 39.142 & 31.441 & 12.282 & - & 0.361 & 3.670 & - & 0.206 & 5.781 & - & 7.092 & - \\
\hline Rapeseed & 6.481 & 28.657 & 38.524 & 0.160 & 1.331 & 9.093 & 0.084 & - & 3.746 & - & 11.925 & - \\
\hline Barley & 57.945 & 19.056 & 8.929 & - & 0.999 & 1.008 & - & 0.086 & 2.673 & - & 4.409 & 4.895 \\
\hline Oat & 37.475 & 33.797 & 12.925 & 0.093 & 1.011 & 1.430 & - & 0.354 & 10.183 & - & 2.735 & - \\
\hline Corn & 34.417 & 35.126 & 19.249 & - & 1.526 & 1.391 & - & 0.146 & 2.632 & 0.186 & 5.327 & - \\
\hline Soybean & 5.244 & 39.498 & 48.760 & 0.172 & 1.477 & 1.536 & 0.156 & 0.124 & 0.428 & - & 2.603 & - \\
\hline Sunflower & 3.496 & 48.252 & 30.302 & - & 0.257 & 1.571 & 0.112 & - & 4.706 & - & 11.304 & - \\
\hline
\end{tabular}

As it can be seen from the data presented in Table 1 and 2 and in Fig 2, the highest content of watersoluble substances is present in the non-grain part of corn (19.8\%), oats (16.1\%) and sunflower (16.1\%); cellulose in straw of barley $(50.0 \%)$, soybeans $(46.9 \%)$ and wheat $(46.5 \%)$; hemicellulose in stalk of sunflower (43.5\%), straw of soybeans (36.3\%) and rapeseed (35.5\%) and lignin in straw of barley (24.2\%), rapeseed $(16.7 \%)$ and rye $(15.5 \%)$.

The results of studies of the composition of lignocellulosic biomass in terms of lignin content and ash content do not coincide with the common conclusions that samples with lower lignin content have lower ash content [25]. Thus, the highest ash rates are in sunflower (14.7\%), corn (9.0\%), and rapeseed $(8.0 \%)$, while the lowest are in soybeans $(4.4 \%)$, rye $(6.2 \%)$, and wheat $(6.5 \%)$.

In general, the above results show that the highest total content of cellulose and hemicellulose is in the non-grain part of legumes - soybeans $(83.2 \%)$ and rapeseed $(79.2 \%)$. This allows us to draw preliminary conclusions about the higher value of these crops for use in the technologies of biofuel obtained by fermentation methods. 


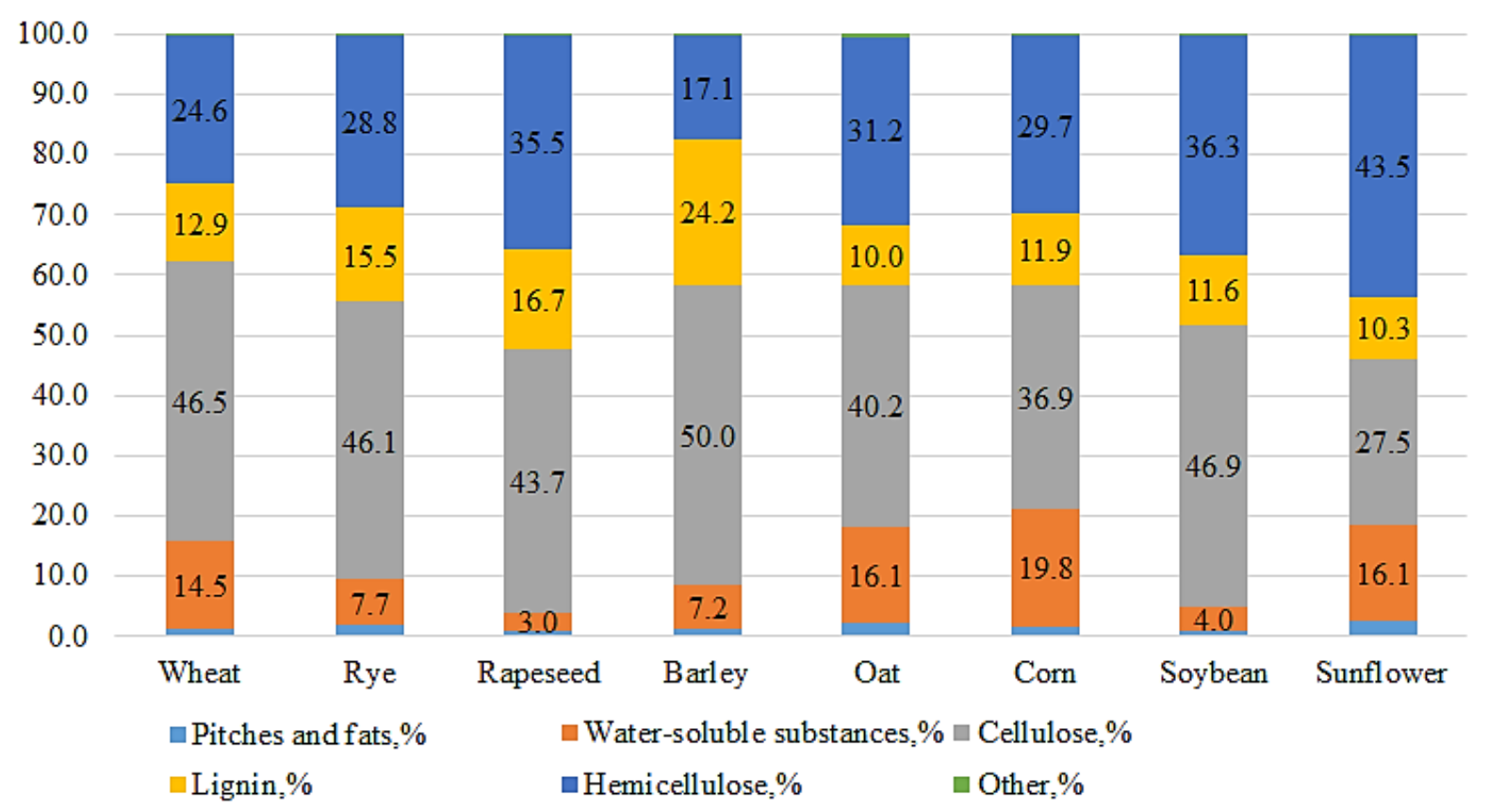

Fig. 2. Composition of lignocellulosic biomass of the non-grain part of major crops

\section{Conclusions}

1. It is found that in the conditions of Ukraine the main plant raw materials for further use in biofuel technologies are the non-grain part of the harvest of the following most common crops: corn, wheat, sunflower, barley, soybean, and rapeseed. The share of the use of these raw materials for the production of energy and solid biofuels currently does not exceed $1 \%$.

2. According to the results of laboratory studies of the parameters and composition of organic raw materials, it was found that the highest content of water-soluble substances is present in the nongrain part of corn $(19.8 \%)$, oats $(16.1 \%)$ and sunflower $(16.1 \%)$; cellulose in straw of barley $(50.0 \%)$, soybeans $(46.9 \%)$ and wheat $(46.5 \%)$; hemicellulose in stalk of sunflower (43.5\%), straw of soybeans $(36.3 \%)$ and rapeseed $(35.5 \%)$ and lignin in straw of barley $(24.2 \%)$, rapeseed $(16.7 \%)$ and rye $(15.5 \%)$.

3. The highest ash content is in the non-grain part of sunflower (14.7\%), corn (9.0\%) and rapeseed $(8.0 \%)$, the lowest is in soybeans $(4.4 \%)$, rye $(6.2 \%)$, and wheat $6.5 \%)$. The non-grain part of legumes - soybeans and rapeseed - is distinguished by the highest total content of cellulose and hemicellulose (83.2\% and 79.2\%, accordingly), which indicates the higher value of these crops for use in technologies of biofuel obtained by fermentation methods.

\section{References}

[1] Binder J. B., Raines R. T. Simple chemical transformation of lignocellulosic biomass into furans for fuels and chemicals. Journal of the American Chemical Society, 131 (5), 2009, pp. 1979-1985.

[2] Pereira Marques F., Lima Soares A. K., Lomonaco D., Alexandre e Silva L. M., Tédde Santaella S., de Freitas Rosa M., \& Carrhá Leitão R. Steam explosion pretreatment improves acetic acid organosolv delignification of oil palm mesocarp fibers and sugarcane bagasse. International Journal of Biological Macromolecules, 175, 2021, pp. 304-312.

[3] Mazur, V.A., Mazur, K.V., Pantsyreva, H.V., Alekseev, O.O. Ecological and economic evaluation of varietal resources Lupinus albus L. in Ukraine. Ukrainian Journal of Ecology, 8,4, 2018, pp. 148153.

[4] Kalis H., Kolmickovs A., Marinaki M., Valdmanis R. Mathematical modelling and experimental study of straw co-firing with gas using electric field control of combustion characteristics. Proceedings of 19th International Scientific Conference "Engineering for Rural Development". Volume 19, 2020, Jelgava, Latvia University of Life Sciences and Technologies, Latvia, pp. 10591064. 
[5] Lourenço A., Gominho J., Pereira H. Chemical Characterization of Lignocellulosic Materials by Analytical Pyrolysis. Analytical Pyrolysis. 2019.

[6] Pang T., Wang G., Sun H., Sui W., Si C. Lignin fractionation: Effective strategy to reduce molecule weight dependent heterogeneity for upgraded lignin valorization. Industrial Crops and Products, 2021, 165.

[7] Cherubini F., Ulgiati S. Crop residues as raw materials for biorefinery systems - A LCA case study. Applied Energy, 87(1), 2010, pp. 47-57.

[8] Karimi M., Jenkins B., Stroeve P. Ultrasound irradiation in the production of ethanol from biomass. Renewable and Sustainable Energy Reviews, 40, 2014, pp. 400-421.

[9] Kumar P., Barrett D.M., Delwiche M.J., Stroeve P. Methods for pretreatment of lignocellulosic biomass for efficient hydrolysis and biofuel production. Ind. Eng. Chem. Res., 48, 8, 2009, pp. 3713-3729.

[10] Alvira P., Tomas-Pejo E., Ballesteros M., Negro M.J. Pretreatment technologies for an efficient bioethanol production process based on enzymatic hydrolysis: a review. Bioresour. Technol., 101, 2010, pp. 4851-4861.

[11] Klymenko V., et al. Prediction of Effective Elasticity Coefficients of Composite Biofuel. Tehnički Glasnik, 14 (2), 2020, pp. 94-99.

[12] Golub G., Tsyvenkova1 N., Chuba V., Yarosh Y. Bulk density of chopped wheat straw - influence of moisture content, fine fraction content and coefficient of compaction. Proceedings of 19th International Scientific Conference "Engineering for Rural Development". Volume 19, 2020, Jelgava, Latvia University of Life Sciences and Technologies, Latvia, pp. 1892-1899.

[13] OECD-FAO Agricultural Outlook 2019-2028, OECD Publishing, Paris. Food and Agriculture Organization of the United Nations, Rome. DOI: 10.1787/agr_outlook-2019-en

[14] The World Bank. Cereal production (metric tons). Food and Agriculture Organization, electronic files and web site. Available at: https://data.worldbank.org/indicator/AG.PRD.CREL.MT

[15] УКАБ. Україна ввійде в ТОП-5 країн-експортерів зерна (UCAB. Ukraine will enter the TOP-5 grain-exporting countries) [online] [20.03.2021] Available at: https://ucab.ua/ua/pres_sluzhba/novosti/ ukraina_vviyde_v_top5_kraineksporteriv_zerna (In Ukrainian).

[16]Гелетуха Г.Г., Желєзна Т.А. Перспективи використання відходів сільського господарства для виробництва енергії в Україні. Аналітична записка Біоенергетичної асоціації України № 7 (Prospects for the use of agricultural waste for energy production in Ukraine. Analytical note of the Bioenergy Association of Ukraine № 7). 25.02.2014. Київ. 33 с. [online] [20.03.2021] Available at: https://uabio.org/wp-content/uploads/2020/04/position-paper-uabio-7-ua.pdf (In Ukrainian).

[17] Дубровін В.О., Кудря С.О., Гелетуха Г.Г. та ін. Методика узагальненої оцінки технічнодосяжного енергетичного потенціалу біомаси (Methods of generalized assessment of technically achievable energy potential of biomass). Київ : ТОВ «Віол-принт», 2013. 25 с. (In Ukrainian).

[18] ISO 6496 Animal feeding stuffs. Determination of moisture content

[19] GOST 24104-88 General purpose laboratory balances and comparison balances. Performance. Specifications

[20] GOST 26226-95. Feeding stuff, mixed feeding stuff and feeding stuff raw material. Method for determination of raw ash

[21] Оболенская А.В., Ельницкая 3.П., Леонович А.А. Лабораторные работы по химии древесины и целлюлозы (Laboratory work on the chemistry of wood and cellulose). М.: Экология, 1991. 321 c. (In Russian).

[22] GOST 26177-84. Fodder, mixed feeds. Method for determination of lignin

[23] Методы биохимического исследования растений (Biochemical research methods of plants). Под ред. А.И. Ермакова. Л.: Колос, 1972. 181 с. (In Russian).

[24] GOST 6841-77. Cellulose. Method for determination of pitch and fat

[25]Бойко I.I., Марчук O.O., Ганженко О.М., Гончарук Г.С. Залежність якості біомаси енергетичної верби від віку плантації та строків збирання врожаю (Dependence of the quality of energy willow biomass on the age of the plantation and the period of harvest). Біоенергетика. № 1 (9). 2017. C. 24-26. (In Ukrainian). 